University of Nebraska - Lincoln

DigitalCommons@University of Nebraska - Lincoln

USDA National Wildlife Research Center - Staff Publications
U.S. Department of Agriculture: Animal and Plant Health Inspection Service

May 2000

\title{
Lethal Control of Piscivorous Birds at Aquaculture Facilities in the Northeast United States: Effects on Populations
}

\author{
Bradley F. Blackwell \\ USDA/APHIS/WS National Wildlife Research Center, bradley.f.blackwell@aphis.usda.gov \\ Richard A. Dolbeer \\ U.S. Department of Agriculture, Animal and Plant Health Inspection Service, Wildlife Services, National \\ Wildlife Research Center, Ohio Field Station \\ Laura A. Tyson \\ U.S. Department of Agriculture, Animal and Plant Health Inspection Service, Wildlife Services, National \\ Wildlife Research Center, Ohio Field Station
}

Follow this and additional works at: https://digitalcommons.unl.edu/icwdm_usdanwrc

Part of the Environmental Sciences Commons

Blackwell, Bradley F.; Dolbeer, Richard A.; and Tyson, Laura A., "Lethal Control of Piscivorous Birds at Aquaculture Facilities in the Northeast United States: Effects on Populations" (2000). USDA National Wildlife Research Center - Staff Publications. 148.

https://digitalcommons.unl.edu/icwdm_usdanwrc/148

This Article is brought to you for free and open access by the U.S. Department of Agriculture: Animal and Plant Health Inspection Service at DigitalCommons@University of Nebraska - Lincoln. It has been accepted for inclusion in USDA National Wildlife Research Center - Staff Publications by an authorized administrator of DigitalCommons@University of Nebraska - Lincoln. 


\title{
Lethal Control of Piscivorous Birds at Aquaculture Facilities in the Northeast United States: Effects on Populations
}

\author{
Bradley F. Blackwell,* Richard A. Dolbeer, and Laura A. Tyson \\ U.S. Department of Agriculture, Animal and Plant Health Inspection Service, \\ Wildlife Services, National Wildlife Research Center, Ohio Field Station, \\ 6100 Columbus Avenue, Sandusky, Ohio 44870, USA
}

\begin{abstract}
Predation by piscivorous birds is considered a substantial threat to the aquaculture industry. However, lethal control of birds at aquaculture facilities has raised concerns about the effects on the distribution and abundance of populations of the species killed. We examined the relationship between numbers of piscivorous birds reported killed under U.S. Fish and Wildlife Service (USFWS) permits at aquaculture facilities in New York, New Jersey, and Pennsylvania and species population trends within the respective states. The USFWS issued 26 permits to 9 facilities from 1985 through September 1997. Eight species appeared on permits, but only six species were reported killed: blackcrowned night-herons Nycticorax nycticorax, doublecrested cormorants Phalacrocorax auritus, great blue herons Ardea herodias, herring gulls Larus argentatus, ring-billed gulls $L$. delawarensis, and mallards Anas platyrhynchos. Over 13 years, the authorized number of birds to be killed per species or group (e.g., gulls) ranged from 5 to $800($ mean $=240, \mathrm{SD}=300)$, whereas the reported number of birds killed per species or group (1985-1996) ranged from 0 to 289 (mean $=83, \mathrm{SD}=$ 118). Across states and species, the number of birds authorized to be killed per permit ranged from 2 to 60 $($ mean $=27, \mathrm{SD}=20)$, whereas reported kills ranged from 0 to $45($ mean $=12, \mathrm{SD}=10)$. Herring gulls $(N$ $=272)$ and great blue herons $(N=163)$ were the most frequently killed species. The number of birds reported killed, relative to systematic long-term population trends, is considered to have had negligible effects on the population status of the respective species.
\end{abstract}

\section{Introduction}

Price and Nickum (1995) projected that by 2000 worldwide aquaculture production would be valued at US $\$ 59$ billion and represent $40 \%$ of world fish production. A crucial factor in the growth of the aquaculture industry has been control of mortality during production. In particular, predation by piscivorous birds is viewed as a substantial threat to the aquaculture industry (Lagler 1939; Parkhurst et al. 1987; Parkhurst 1994; Glahn and Brugger 1995; Glahn et al. 1999a, 1999b). For

* Corresponding author: bradley.f.blackwell@usda.gov Received January 24, 2000; accepted May 30, 2000 example, predation by double-crested cormorants Phalacrocorax auritus on channel catfish Ictalurus punctatus at aquaculture facilities in the Mississippi Delta represented replacement costs of $\$ 2$ million annually (Glahn and Brugger 1995). Avian predation is also a problem for aquaculture operations in the northeast United States (Glahn et al. 1999a, 1999b), which produces primarily rainbow trout Oncorhynchus mykiss, brown trout Salmo trutta, and brook trout Salvelinus fontinalis, as well as warmwater species, including baitfish, channel catfish, and goldfish Carassius auratus. Avian predation inflicts not only direct mortality, but also injury and stress that can negatively affect fish feeding and growth. In addition, concern exists that avian predators might spread diseases among aquaculture facilities (Price and Nickum 1995).

Nonlethal techniques are available to control depredation by piscivorous birds at aquaculture facilities (Mott and Boyd 1995; Mott and Flynt 1995). The cost-effectiveness of these methods, for example, roost dispersal (Mott et al. 1992), or exclusion devices at rearing ponds (Mott and Flynt 1995; Mott et al. 1995) — varies by facility, predator species, and extent of losses (Trapp et al. 1995; Glahn et al. 1999b). Only after an aquaculture operation has demonstrated efforts to control avian predation via nonlethal means will the U.S. Fish and Wildlife Service (USFWS) consider issuing a depredation permit (Code of Federal Regulations, Title 50, Part 21; see also USFWS 1998 for standing depredation order against doublecrested cormorants in specified states).

Dolbeer (1998) noted that justification and defense of lethal or reproductive control programs to solve vertebrate pest problems require a sound understanding of the population status and dynamics of the problem species. Lethal control of depredating birds at aquaculture facilities, though intended to enhance the effectiveness of nonlethal methods (Mastrangelo et al. 1997), has raised concerns because of the insufficient understanding of predator-prey relationships, movements, and pop- 
ulation dynamics of the target species (Erwin 1995; Nisbet 1995). Additional questions remain as to the effects of lethal control programs on distribution and abundance of local, regional, and national populations of species targeted by depredation permits (Erwin 1995; Trapp et al. 1995; Belant et al. 2000).

We examined the relationship between speciesspecific numbers of birds reported killed under permit at aquaculture facilities in New York (NY), New Jersey (NJ), and Pennsylvania (PA) and population trends, both within the respective states and regionally. Constituents of the Northeastern Regional Aquaculture Center at the University of Massachusetts Dartmouth from these three states expressed interest in an evaluation of the permitting process.

Our objectives were to (1) determine the number of applications for avian depredation permits received by the USFWS for aquaculture facilities in NY, NJ, and PA, the number of permits issued, the species and number of individuals authorized to be killed, and the species and numbers reported killed; (2) determine the criteria under which depredation permits were denied; and (3) evaluate the relative effects on populations of species reported killed under depredation permits.

\section{Methods}

Depredation permits.-Records of avian depredation permit applications by aquaculture facilities in NY, NJ, and PA (1985 through September 1997) were provided by the USFWS Migratory Bird Management Office (MBMO) in Hadley, Massachusetts. The MBMO records included copies of facility communications to the USFWS documenting predation losses, Migratory Bird Damage Reports, USFWS communications that specified reasons for permit denials, permitted species and number of birds authorized to be killed, and final (year-end) reports from the facilities documenting species and numbers killed. Permit data before 1985 were unavailable because records had been destroyed or were in unmarked bulk storage (D. M. Pence, MBMO, personal communication). Annual reports (documenting species and numbers killed) from facilities receiving permits in 1997 were not available at the time of this study. Also, data relative to state denials of facility requests to apply for federal depredation permits were not included in the MBMO records, unless an application was received without evidence of state approval. In addition, species and numbers of indi- viduals reported killed under permit were not verified by the MBMO.

Population statistics. - To evaluate potential population effects on an avian species identified on permits and reported killed, we examined longterm systematic survey data for the respective state and period. Data for species population trends were obtained from the North American Breeding Bird Survey (BBS; Sauer et al. 1997) and the National Audubon Society (NAS) Christmas Bird Count (CBC; Sauer et al. 1996) databases. Though these surveys have inherent limitations (see Butcher and McCulloch 1990; Sauer et al. 1997), they represent the only systematically collected, longterm population data available for most avian species.

The BBS comprises approximately 3,700 randomly located survey routes (39.4 $\mathrm{km}$ each) throughout the continental United States, Canada, and Alaska that are surveyed annually in June (Peterjohn and Sauer 1993). Each route has 50 stops (at $0.8-\mathrm{km}$ intervals) at which all birds seen within $0.4 \mathrm{~km}$ or heard at any distance are tallied during a 3-min point count (Robbins et al. 1986). We used breeding population trend (mean percent change per year) estimates for 1966 through 1996 for each state and the associated population indices (deviations from the breeding population trend; Sauer et al. 1997).

Because some species pose depredation problems in states outside their breeding range, the BBS was not applicable in all cases. To examine trends in the winter concentration of piscivorous birds in the three states, we used the $\mathrm{CBC}$. The annual $\mathrm{CBC}$ is an early winter, 1-d survey of birds on approximately 1,700 nonoverlapping circles (24.1-km diameter) located (in a nonrandom procedure) throughout the United States and Canada, and in parts of Mexico, Central America, and the Caribbean islands (Butcher and McCulloch 1990; Sauer et al. 1996). Trend (mean percent change per year) and mean relative abundance (mean number of birds/100 party hours) estimates were available for CBCs in each state for 1959 (counts conducted in December 1959 and January 1960) through 1988 (Sauer et al. 1996). In addition, we calculated mean relative abundance estimates from raw CBC data for 1989 through 1996 (NAS American Birds 42, 88th CBC through NAS Field Notes 51, 97th CBC).

We then used Pearson's product-moment correlation to assess the association between the number of individuals per species killed annually in each state and the respective BBS species popu- 
TABLE 1.-Species and number of piscivorous birds authorized to be killed and reported killed at aquaculture facilities in New York (NY), New Jersey (NJ), and Pennsylvania (PA), 1985-1997. Blanks indicate unavailable data.

\begin{tabular}{llrrr}
\hline \multicolumn{1}{c}{ Species } & State & $\begin{array}{c}\text { Authorized } \\
\text { to be killed }\end{array}$ & $\begin{array}{c}\text { Reported } \\
\text { killed }\end{array}$ & $\begin{array}{c}\text { Percent of } \\
\text { authorized } \\
\text { number } \\
\text { killed }\end{array}$ \\
\hline Double-crested cormorant & PA & 5 & 5 & 100 \\
Herring gull a $_{\text {Ring-billed gull b }}$ & NJ & 750 & 272 & 36 \\
Black-crowned night-heron & PA & 50 & 17 & 34 \\
Great blue heron & PA & 65 & 18 & 28 \\
& NY & 4 & & \\
Green heron & NJ & 144 & 116 & 80 \\
Mallard & PA & 97 & 47 & 48 \\
All species & PA & 25 & 0 & 0 \\
& NJ & 300 & 21 & 7 \\
& NY & 4 & & 34 \\
\hline
\end{tabular}

a Twenty-seven gulls not identified to species and 10 of 12 permits not species specific.

${ }^{b}$ Permit also authorized herring and laughing gulls in any combination.

lation indices or $\mathrm{CBC}$ mean relative abundance estimates for each subsequent year. Correlation coefficients were calculated only for species in which kills were reported for five or more years. The critical region for all comparisons was $P<0.05$.

We also referenced Breeding Bird Atlases as indices of species breeding distributions within a state over a 5-10 year period (Robbins 1990). Each state atlas represented species breeding distributions mapped relative to a grid of blocks (total number varied among states), representing approximately $25 \mathrm{~km}^{2}$ each. Though not comparable with records of the number of individuals per species reported killed annually in each state, atlas data provided a spatial index of species population status. When neither the BBS, CBC, or Breeding Bird Atlas provided information on the status of a species killed under depredation permit, we referenced published regional population estimates and state natural resource agency records.

\section{Results}

\section{Depredation Permits}

During 1985 through September 1997, the MBMO received 30 applications for control of piscivorous birds from 10 aquaculture facilities (1 in west-central NY, 3 in northeast and east-central NJ, and 6 located in south-central, east-central, or southeast PA). Nine facilities received permits, and 26 permits (17 in NJ, 8 in PA, and 1 in NY) were issued. Four of the 10 facilities were denied permits during the 13 years (one facility applied once and was denied). Permits were denied because operators did not respond to USFWS requests to document nonlethal management efforts (one permit in PA), obtain state approval to control depredating birds (one in PA), or include documentation of an environmental assessment (two in NJ). Facilities required to perform environmental assessments were to address the historical and anticipated take under the permit and impacts on the flyway, regional, and state populations of the target species. We note, however, that an environmental assessment is not a prerequisite for receiving a depredation permit (Code of Federal Regulations, Title 50, Part 21).

Great blue herons Ardea herodias appeared most frequently $(96 \%)$ on depredation permits, followed by herring gulls Larus argentatus, laughing gulls L. atricilla, and ring-billed gulls $L$. delawarensis (61\%). Mallards Anas platyrhynchos (23\%), blackcrowned night-herons Nycticorax nycticorax (19.2\%), green herons Butorides virescens (4\%), and double-crested cormorants (4\%) were also represented. We assumed that permits listing "gulls" only included the three species listed above. The number of species identified per permit ranged from one to six (mode $=$ four).

From 1985 through 1997, the authorized number of birds to be killed per species or species group (e.g., gulls) ranged from 5 to 800 (mean $=240$, $\mathrm{SD}=300)$. Facilities in NJ were responsible for $83 \%$ of the quota (Table 1). By state, the all-year (13 years) total authorized number of individuals to be killed per species or group ranged from 4 to $750($ mean $=160, \mathrm{SD}=240 ;$ Table 1$)$ and from 3 to 100 (mean $=37, \mathrm{SD}=30$ ) annually (Appendix). By permit, the total authorized number of individuals to be killed per species or group ranged from 2 to $60($ mean $=27, \mathrm{SD}=20)$. 
TABLE 2.- North American Breeding Bird Survey trends (1966-1996) for piscivorous bird species killed under depredation permits at aquaculture facilities in New York (NY), New Jersey (NJ), and Pennsylvania (PA), 1985-1996.

\begin{tabular}{lcrrrr}
\hline & & & \multicolumn{3}{c}{ Annual percent change } \\
\cline { 5 - 6 } \multicolumn{1}{c}{ Species } & State & Routes & Mean & SE & $P$ \\
\hline Black-crowned night-heron & PA & 5 & 13.0 & 2.0 & $>0.05$ \\
Great blue heron & NJ & 33 & 0.7 & 0.3 & $>0.05$ \\
& PA & 61 & 4.5 & 0.1 & $<0.01$ \\
Herring gull & NJ & 8 & -4.3 & 5.7 & $>0.05$ \\
Ring-billed gull & PA & 3 & 15.5 & 5.0 & $>0.05$ \\
Mallard & NJ & 24 & 3.5 & 1.4 & $>0.05$ \\
\hline
\end{tabular}

\section{Reported Kills}

The reported number of birds killed annually per species or group ranged from 0 to 289 (mean $=83, \mathrm{SD}=118$ ) for 1985 through 1996 . Facilities in NJ were responsible for over $82 \%$ of the reported kills (Table 1). By state, the all-year total for reported number of birds killed per species or group ranged from 0 to 272 (mean $=62, \mathrm{SD}=$ 93) for the 13 years (Table 1) and from 0 to 55 $($ mean $=15, \mathrm{SD}=15)$ annually (Appendix). By permit, the reported number of birds killed per species or group ranged from 0 to 45 (mean $=12$, $\mathrm{SD}=10$ ) annually. Only individuals from six of the eight species approved on permits were reported killed (Table 1). We note, however, that a final report to the MBMO from a facility in $\mathrm{NJ}$ (authorized to take 10 great blue herons, 50 gulls, and 50 mallards during 1986) was unavailable.

\section{Population Effects}

Great blue herons appeared on permits in each of the three states and represented the only species listed on the one permit issued in NY (Table 1). In NJ, a mean of $13(\mathrm{SD}=6)$ great blue herons was reported killed annually from 1985 through 1996 (Appendix). Annual reported kills were not negatively correlated $(r=0.83, P=0.001$, df $=$ 7 ) with BBS population indices. Furthermore, although the BBS trend indicated that the great blue heron population was not increasing from 1966 through 1996 (Table 2), Walsh et al. (1998) reported that the species' range was expanding north to south in NJ (general area of aquaculture facilities noted above). Specifically, between 1993 and 1997, great blue herons were recorded in $18.2 \%$ ( $N=155)$ of atlas blocks, and confirmed nesting in $4.8 \%(N=41$; Walsh et al. 1998).

In PA, an annual mean of $16(\mathrm{SD}=10)$ great blue herons was reported killed during 1993, 1995, and 1996 (Appendix). The species exhibited growth in the breeding population from 1966 through 1996, according to the BBS trend (Table
2). Between 1983 and 1989, great blue herons were observed in $46.2 \%(N=2,279)$ of atlas blocks (statewide) and confirmed as nesting in $2.3 \%(N$ $=114$ ), primarily in northwest PA (Schwalbe and Ross 1992). From 1977 through 1997, 138 great blue heron colonies were located in PA; however, all areas were not searched annually. The most extensive aerial survey (1997) found 73 colonies containing 1,320 nesting pairs primarily in west, northwest, north-central, and northeast PA (D. Braunning, Pennsylvania Game Commission, unpublished data).

Herring gulls appeared on depredation permits in NJ and PA (Table 1), but only NJ facilities reported kills $($ mean $=30, \mathrm{SD}=18$ birds annually, 1985-1996). The BBS population trend for the species indicated no change from 1966 through 1996 (Table 2). Annual reported kills were not correlated with BBS population indices $(r=$ $-0.19, P=0.194$, df $=7$ ). In addition, between 1993 and 1997 herring gulls were confirmed as nesting in $2.7 \%(N=23)$ of $\mathrm{NJ}$ atlas blocks (Walsh et al. 1998). Furthermore, 6,828 nests were discovered in 121 colonies (primarily along the southern coast) during a 1995 coastal waterbird survey (B. Hoover, U.S. Geological Survey, Biological Resources Division, Patuxent Wildlife Research Center, unpublished data). Also, because herring gulls generally breed from NY northward (Bent 1963), migrating birds may influence NJ aquaculture. Mean relative abundance estimates of herring gulls on CBC circles in NJ have increased from 245 birds $(1959-1988, N=31$ circles $)$ to 2,121 birds from 1989 through $1996(N=30$ circles $)$.

Mallards appeared on depredation permits only in NJ (Table 1) and over a 6-year period, but only in 1987 were kills reported (Appendix). Parkhurst et al. (1987) reported that $28 \%$ of fish hatchery managers surveyed, predominantly from the eastern United States $(N=175)$, considered the mallard as a predator. The breeding population of mallards in $\mathrm{NJ}$, according to the BBS, exhibited no 
change from 1966 through 1996 (Table 2). However, between 1993 and 1997, individuals were observed in $77.5 \%(N=660)$ of atlas blocks and were confirmed to be nesting in $55.5 \%(N=471$; Walsh et al. 1998). Furthermore, the mallard breeding population in the northeast United States averaged 365,000 nesting pairs from 1955 through 1995 , and an estimated 397,500 pairs nested in the northeast United States in 1997 (Caithamer and Dubovsky 1997).

Black-crowned night herons appeared on depredation permits in PA only (Table 1), and facilities reported an annual mean kill of four birds (1993-1996; Appendix). The breeding population of black-crowned night herons, based on the BBS, showed no change from 1966 through 1996 (Table 2). The most recent Breeding Bird Atlas survey (1983-1989) indicated that the species was observed in $3.0 \%(N=152)$ of atlas blocks (statewide) and was confirmed as nesting in $0.4 \%(N=$ 18 ), primarily in southeast PA (Schutsky 1992). Between 1993 and 1997, years when the species was listed on depredation permits, a mean of 219 $(\mathrm{SD}=169)$ nests per year were located in nine colonies (Brauning, unpublished data).

Ring-billed gulls were listed on depredation permits in NJ and PA, but kills were reported only in PA and during 1996 (Table 1). The breeding range of the species does not include PA and NJ (see Bent 1963). However, the species was frequently observed on CBC circles in PA (1959-1988: $N=$ 50 circles, mean relative abundance $=830$ birds; 1989-1996: $N=67$ circles, mean relative abundance $=1,065$ birds).

The double-crested cormorant was listed on a single depredation permit, in PA (Table 1). Though observed during the BBS in PA, the species was not considered as nesting (Brauning 1992). We note, however, that one nesting pair was discovered in 1996 (D. Brauning, PGC, unpublished data). Likewise, double-crested cormorants were seen infrequently on $\mathrm{CBC}$ circles (mean relative abundance $=1$ bird, $N=67$ circles, 1989-1996). However, an estimated 85,510 pairs nested from NJ through northeastern Canada in 1993. The total population in the United States and Canada in 1997 was estimated at approximately 1 million individuals (Tyson et al., 1999).

\section{Discussion}

Conflicts between avian and human interests have increased in North America in recent years, corresponding to increases in certain avian populations (Blokpoel and Tessier 1986; Dolbeer and
Bernhardt 1986; Belant 1997; Tyson et al., 1999). However, the Migratory Bird Treaty Act of 1918 protects avian piscivores within the United States (16 U.S.C. 703-711). Currently, regulations pertaining to the issuance of permits to control depredating birds (Code of Federal Regulations, Title 50, Part 21) dictate that no federally designated threatened or endangered species can appear on a depredation permit, nor can the proposed action violate respective state ordinances. However, because the ecology of avian piscivores is often poorly understood (Erwin 1995; Nisbet 1995), no management option to reduce predation losses has been more controversial than lethal control.

We found that species appearing on depredation permits in NY, NJ, and PA (1985-1997) were not listed on federal threatened or endangered lists, and only the great blue heron was listed by a state (as threatened in $\mathrm{NJ}$ ). However, great blue herons and herring gulls were well represented locally and regionally, although they were the two species most frequently listed on depredation permits and reported killed at aquaculture facilities in the three states. In addition, permit data indicate that the numbers of birds per species or group killed at aquaculture facilities in the northeast United States from 1985 through 1996 (generally less than 20 birds annually) represented, on average, less than half the authorized take. Relative to long-term population trends for species killed in each of the three states, this level of reported kill was negligible. Further, with the exception of the blackcrowned night-heron in NJ, breeding distribution data indicate that species populations killed under depredation permits were well established within the respective state or region. Similarly, Belant et al. (2000) found that the reported number of birds killed under permit at aquaculture facilities in the southeastern United States (1987-1995) had no adverse effect on regional winter or continental breeding populations, although the kills were substantially greater than reported kills in the northeast United States (e.g., double-crested cormorants $=35,332$ birds or $64 \%$ of authorized take; great blue herons $=13,364$ birds or $65 \%$ of authorized take).

Although lethal control of piscivorous birds may prompt opposition because of potentially negative population effects, the positive effects of aquaculture (i.e., an increased, concentrated, and dependable food supply) have not been fully assessed. Fleury and Sherry (1995) reported that population trends for multiple species of colonial wading birds in Louisiana were positively corre- 
lated with increased acreage devoted to the culture of red swamp crayfish Procambarus clarkii. Likewise, channel catfish aquaculture production in the Delta region of Mississippi is considered a prominent factor influencing the winter distribution of double-crested cormorants (Glahn and Stickley 1995) and may increase their survival by improving body condition (e.g, premigratory fat deposition; Glahn et al., 1999). For avian piscivors in the northeast United States, population assessments have not been made relative to trends in regional aquaculture production.

Still, evaluations of population-level effects of lethal control at aquaculture facilities can be improved by increasing the availability of MBMO records and the accuracy of the information. For example, the remaining historical depredation permit records (before 1985) should be included in the USFWS database so that long-term trends in species authorized and reported killed can be examined relative to trends in both regional aquaculture production and species populations. Also, aquaculture facilities holding depredation permits are responsible for detailing periods and severity of predation, dates of kills, and the number of birds taken by species. Unauthorized take of birds or poor record keeping by the permit holder is illegal and biases the information provided to the USFWS. Of 21 annual reports, 10 provided incomplete information on numbers of birds killed or dates of kills. Further, in NJ, 12 permits were issued for gull depredation, without limiting the take to particular species. Although 10 of the 12 subsequent annual reports from NJ facilities included kills of herring gulls, 2 provided no information on species killed.

Further, as Glahn et al. (1999a) noted, additional research is needed to directly measure actual fish production losses to avian predation. These data will also allow better evaluation of seasonal energetic contribution of cultured fish to regional avian piscivore populations. In addition, we concur with Trapp et al. (1995) that there is need for continued research on nonlethal techniques to reduce predation losses at aquaculture facilities. However, because of the limitations and costs associated with nonlethal techniques, we also suggest researching the effectiveness of lethal control in enhancing nonlethal management at aquaculture facilities. Improving our understanding of the ecology of piscivorous birds, making efficient use of permit and population data, and improving nonlethal management methods will enable better management of both predation losses at aquacul- ture facilities and the species populations involved.

\section{Acknowledgments}

This work was supported in part by the Northeastern Regional Aquaculture Center at the University of Massachusetts Dartmouth, through grant 96-38500-3032 from the Cooperative State Research, Education and the Extension Service of the U.S. Department of Agriculture. We thank J. L. Belant, D. W. Brauning, J. L. Bucknall, R. B. Chipman, J. L. Dyer, N. N. Flemming, B. Hoover, C. D. Jenkins, A. J. Montoney, D. M. Pence, B. G. Peterjohn, J. Serie, L. A. Sommers, T. T. Tomsa, and $\mathrm{J}$. Walsh for providing advice and assistance in data collection. M. L. Avery, J. L. Bucknall, J. F. Glahn, P. B. Hamel, M. E. Tobin, and SE Wright provided helpful reviews of the manuscript.

\section{References}

Belant, J. L. 1997. Gulls in urban environments: landscape-level management to reduce conflict. Landscape and Urban Planning 38:245-258.

Belant, J. L., L. A. Tyson, and P. M. Mastrangelo. 2000. Effects of lethal control at aquaculture facilities on populations of piscivorous birds. Wildlife Society Bulletin 27:379-384.

Bent, A. C. 1963. Life histories of North American gulls and terns. Dover, New York.

Blokpoel, H., and G. D. Tessier. 1986. The ring-billed gull in Ontario: a review of a new problem species. Canadian Wildlife Service, Occasional Paper 57, Ottawa.

Brauning, D. W., editor. 1992. Atlas of breeding birds in Pennsylvania. University of Pittsburgh Press, Pittsburgh, Pennsylvania.

Butcher, G. S., and C. E. McCulloch. 1990. Influence of observer effort on the number of individual birds recorded on Christmas bird counts. Pages 120-129 in J. R. Sauer and S. Droege, editors. Survey designs and statistical methods for the estimation of avian population trends. U.S. Fish and Wildlife Service Biological Report 90(1).

Caithamer, D. F., and J. A. Dubovsky. 1997. Waterfowl population status, 1997. U.S. Fish and Wildlife Service, Office of Migratory Bird Management, Branch of Surveys and Assessment, Laurel, Maryland.

Dolbeer, R. A. 1998. Population dynamics: the foundation of wildlife damage management for the $21 \mathrm{st}$ century. Pages 2-11 in R. O. Baker and A. C. Crabb, editors. Proceedings of the 18th Vertebrate Pest Conference. University of California, Davis.

Dolbeer, R. A., and G. E. Bernhardt. 1986. Early-winter population trends of gulls on western Lake Erie, 1950-84. American Birds 40:1096-1102.

Erwin, R. M. 1995. The ecology of cormorants: some research needs and recommendations. Colonial Waterbirds 18:240-246.

Fleury, B. E., and T. W. Sherry. 1995. Long-term pop- 
ulation trends of colonial wading birds in the southern United States: the impact of crayfish aquaculture on Louisiana populations. Auk 112:613-632.

Glahn, J. F., and K. E. Brugger. 1995. The impact of double-crested cormorants on the Mississippi Delta catfish industry: a bioenergetics model. Colonial Waterbirds 18:168-175.

Glahn, J. F., E. S. Rasmussen, T. Tomsa, and K. J. Preusser. 1999a. Distribution and relative impact of avian predators at aquaculture facilities in the northeastern United States. North American Journal of Aquaculture 61:340-348.

Glahn, J. F., and A. R. Stickley, Jr. 1995. Wintering double-crested cormorants in the Delta Region of Mississippi: population levels and their impact on the catfish industry. Colonial Waterbirds 18:137142.

Glahn, J. F., M. E. Tobin, and J. B. Harrel. 1999. Possible effects of catfish exploitation on over-winter body condition of double-crested cormorants. Pages 107-114 in M. E. Tobin, editor. Symposium on double-crested cormorants: population status and management issues in the Midwest. Midwest Fish and Wildlife Conference 59. Technical Bulletin 1879, U.S. Department of Agriculture, Animal and Plant Health Inspection Service, Washington, D.C.

Glahn, J. F., T. Tomsa, and K. J. Preusser. 1999b. Impact of great blue heron predation at trout-rearing facilities in the northeast United States. North American Journal of Aquaculture 61:349-354.

Lagler, K. F. 1939. The control of fish predators at hatcheries and rearing stations. Journal of Wildlife Management 3:169-179.

Mastrangelo, P., C. Sloan, and K. Bruce. 1997. Incorporating depredation permits into integrated damage management plans for aquaculture facilities. Proceedings of the Eastern Wildlife Damage Management Conference 7:36-43.

Mott, D. F., K. J. Andrews, and G. A. Littauer. 1992. An evaluation of roost dispersal for reducing cormorant activity on catfish ponds. Proceedings of the Eastern Wildlife Damage Control Conference 5: 205-211.

Mott, D. F., and F. L. Boyd. 1995. A review of techniques for preventing cormorant depredations at aquaculture facilities in the southeastern United States. Colonial Waterbirds 18:176-180.

Mott, D. F., and R. D. Flynt. 1995. Evaluation of an electric fence system for excluding wading birds at catfish ponds. Progressive Fish-Culturist 57:88-90.

Mott, D. F., R. D. Flynt, and J. O. King. 1995. An evaluation of floating ropes for reducing cormorant damage at catfish ponds. Proceedings of the Eastern Wildlife Damage Control Conference 6:93-97. North Carolina Cooperative Extension Service, Raleigh.

Nisbet, I. C. T. 1995. Biology, conservation and management of the double-crested cormorant: symposium summary and overview. Colonial Waterbirds $18: 247-252$.

Parkhurst, J. A. 1994. An overview of avian predation and management techniques at fish-rearing facilities. Pages 235-242 in W. S. Halverson and A. C. Crabb, editors. Proceedings of the 16th Vertebrate Pest Conference. University of California, Davis.

Parkhurst, J. A., R. P. Brooks, and D. E. Arnold. 1987. A survey of wildlife depredation and control techniques at fish-rearing facilities. Wildlife Society Bulletin 15:386-394.

Peterjohn, B. G., and J. R. Sauer. 1993. North American breeding bird survey annual summary 1990-1991. Bird Populations 1:52-67.

Price, I. M., and J. G. Nickum. 1995. Aquaculture and birds: the context for controversy. Colonial Waterbirds 18:33-45.

Robbins, C. S. 1990. Use of breeding bird atlases to monitor population change. Pages 19-22 in J. R. Sauer and S. Droege, editors. Survey designs and statistical methods for the estimation of avian population trends. U.S. Fish and Wildlife Service Biological Report 90(1).

Robbins, C. S., D. Bystrak, and P. H. Geissler. 1986. The breeding bird survey: its first fifteen years, 1965-1979. U.S. Fish and Wildlife Service, Resource Publication 157, Washington, D.C.

Sauer, J. R., J. E. Hines, G. Gough, I. Thomas, and B. G. Peterjohn. 1997. The North American breeding bird survey results and analysis, version 96. 3. Patuxent Wildlife Research Center, Laurel, Maryland.

Sauer, J. R., S. Schwartz, and B. Hoover. 1996. The Christmas bird count home page, version 95.1. Patuxent Wildlife Research Center, Laurel, Maryland.

Schutsky, R. M. 1992. Black-crowned night heron. Pages 60-61 in D. W. Brauning, editor. Atlas of breeding birds in Pennsylvania. University of Pittsburgh Press, Pittsburgh, Pennsylvania.

Schwalbe, P. W., and R. M. Ross. 1992. Great blue heron. Pages 50-51 in D. W. Brauning, editor. Atlas of breeding birds in Pennsylvania. University of Pittsburgh Press, Pittsburgh, Pennsylvania.

Trapp, J. L., T. J. Dwyer, J. J. Doggett, and J. G. Nickum. 1995. Management responsibilities and policies for cormorants: United States Fish and Wildlife Service. Colonial Waterbirds 18:226-230.

Tyson, L. A., J. L. Belant, F. J. Cuthbert, and D. V. C. Weseloh. 1999. Nesting populations of doublecrested cormorants in the United States and Canada. Pages 17-26 in M. E. Tobin, editor. Symposium on the double-crested cormorant: population status and management issues in the Midwest. Midwest Fish and Wildlife Conference 59. Technical Bulletin 1879, U.S. Department of Agriculture, Animal and Plant Health Inspection Service, Washington, D.C.

USFWS (United States Fish and Wildlife Service). 1998. Migratory bird permits; establishment of a depredation order for the double-crested cormorant, Final Rule (RIN 1018-AE11). Code of Federal Regulations, Title 50, Part 21. U.S. Government Printing Office, Washington, D.C.

Walsh, J., V. Elia, R. Kane, and T. Halliwell. 1998. Birds of New Jersey. New Jersey Audubon Society, Cape May, New Jersey. 
Appendix: Piscivorous Birds Killed at Aquaculture Facilities.

TABLE A.1.-Annual summary of piscivorous birds authorized to be killed and reported killed at aquaculture facilities in New York (NY), New Jersey (NJ), and Pennsylvania (PA), 1985 through 1997. Gulls were generally not identified to species. Blanks indicate that data were unavailable.

\begin{tabular}{|c|c|c|c|c|c|}
\hline \multirow[b]{2}{*}{ Year } & \multirow[b]{2}{*}{ State } & \multirow[b]{2}{*}{ Species } & \multicolumn{2}{|c|}{ Number killed } & \multirow{2}{*}{$\begin{array}{c}\text { Percent of } \\
\text { authorized } \\
\text { number } \\
\text { killed }\end{array}$} \\
\hline & & & Authorized & Reported & \\
\hline \multirow[t]{2}{*}{1985} & \multirow[t]{2}{*}{$\mathrm{NJ}$} & Great blue heron & 5 & 5 & 100 \\
\hline & & Gull & 50 & 15 & 30 \\
\hline \multirow[t]{3}{*}{1986} & \multirow[t]{3}{*}{ NJ } & Great blue heron & 20 & 4 & 20 \\
\hline & & Gull & 100 & 8 & 8 \\
\hline & & Mallard & 50 & 0 & 0 \\
\hline \multirow[t]{3}{*}{1987} & \multirow[t]{3}{*}{$\mathrm{NJ}$} & Great blue heron & 10 & 10 & 100 \\
\hline & & Gull & 50 & 16 & 32 \\
\hline & & Mallard & 50 & 21 & 42 \\
\hline \multirow[t]{2}{*}{1989} & \multirow[t]{2}{*}{$\mathrm{NJ}$} & Great blue heron & 10 & 10 & 100 \\
\hline & & Gull & 50 & 17 & 34 \\
\hline \multirow[t]{3}{*}{1990} & \multirow[t]{3}{*}{$\mathrm{NJ}$} & Great blue heron & 20 & 20 & 100 \\
\hline & & Gull & 100 & 22 & 22 \\
\hline & & Mallard & 50 & 0 & 0 \\
\hline \multirow[t]{3}{*}{1991} & \multirow[t]{3}{*}{$\mathrm{NJ}$} & Great blue heron & 20 & 18 & 90 \\
\hline & & Gull & 100 & 55 & 55 \\
\hline & & Mallard & 50 & 0 & 0 \\
\hline \multirow[t]{3}{*}{1992} & \multirow[t]{3}{*}{$\mathrm{NJ}$} & Great blue heron & 20 & 20 & 100 \\
\hline & & Gull & 100 & 48 & 48 \\
\hline & & Mallard & 50 & 0 & 0 \\
\hline \multirow[t]{4}{*}{1993} & \multirow[t]{2}{*}{$\mathrm{NJ}$} & Great blue heron & 12 & 11 & 92 \\
\hline & & Gull & 50 & 40 & 80 \\
\hline & \multirow[t]{2}{*}{ PA } & Black-crowned night-heron & 25 & 7 & 28 \\
\hline & & Great blue heron & 10 & 10 & 100 \\
\hline \multirow[t]{4}{*}{1994} & \multirow[t]{3}{*}{$\mathrm{NJ}$} & Great blue heron & 24 & 18 & 75 \\
\hline & & Gull & 90 & 51 & 57 \\
\hline & & Mallard & 50 & 0 & 0 \\
\hline & PA & Black-crowned night-heron & 10 & 0 & 0 \\
\hline \multirow[t]{2}{*}{1995} & \multirow[t]{2}{*}{ PA } & Black-crowned night-heron & 10 & 6 & 60 \\
\hline & & Great blue heron & 10 & 10 & 100 \\
\hline \multirow[t]{5}{*}{1996} & PA & Black-crowned night-heron & 10 & 5 & 50 \\
\hline & & Great blue heron & 35 & 27 & 77 \\
\hline & & Double-crested cormorant & 5 & 5 & 100 \\
\hline & & Green heron & 25 & 0 & 0 \\
\hline & & Gull & 50 & 17 & 34 \\
\hline 1997 & NY & Great blue heron & 4 & & \\
\hline & NJ & Great blue heron & 42 & & \\
\hline
\end{tabular}

